\title{
Enjoying the heat? Co-creation of stakeholder benefits and sus- tainable energy development within projects in the geothermal sector
}

\author{
David Cook ${ }^{1 *}$, Ingibjörg Karlsdóttir ${ }^{2}$ and Inga Minelgaite ${ }^{3,}$
}

1 Environment and Natural Resources, Faculty of Economics and Faculty of Environment and Life Sciences, University of Iceland, Gimli, Sæmundargötu 2, 102 Reykjavík, Iceland; dac@hi.is

2 Faculty of Business Administration, University of Iceland, Gimli, Sæmundargötu 2, 102 Reykjavík, Iceland; ink14@hi.is

3 Faculty of Business Administration, University of Iceland, Gimli, Sæmundargötu 2, 102 Reykjavík, Iceland; $\underline{\text { inm } @ \text { hi.is }}$

* Correspondence: dac@hi.is;

\begin{abstract}
Despite knowledge concerning stakeholders and the economic advantages of consultation, collaboration and innovation, analysis of the sustainability implications of the geothermal industry has tended to take a high-level or systemic overview of national performance. This study seeks to begin to fill this gap in the academic and grey literature, investigating the following research question: how do projects in the Icelandic geothermal energy sector create co-benefits with stakeholders and reflect the integration of sustainable energy development (SED)? The focus of its analysis is on identifying who are the stakeholders, what are the sustainability benefits co-created with stakeholders, and when in the project lifecycle do these occur. Based on eleven semi-structured interviews with project managers in Iceland's geothermal industry, the study identifies a broad array of stakeholders in the sector, including national and municipal governments and public sector institutions, businesses, the public, employees and landowners. The sustainability co-benefits of Iceland's geothermal power projects are broad and cut cross all six themes of SED and multiple phases of the project lifecycle. Although the sustainability benefits are very apparent, trade-offs are reported between the pursuit of an economically efficient energy system and nature conservation. This relates to unsustainable utilization of the resources and the environmental externalities of power production and consumption. Efforts to mitigate these effects are ongoing and the further pursuit of SED is likely in Iceland given its recognition within the nation's new energy policy and to meet ambitious greenhouse gas emissions reduction targets in the government's climate action plan. These are issues that are prominent in other nations seeking to decarbonize energy systems through increased utilization of geothermal resources.
\end{abstract}

Keywords: Project management; geothermal; co-benefits; sustainable development; innovation, operationalization

\section{Introduction}

Over the past one-hundred years, geothermal energy resources have been harnessed indirectly to provide base-load electricity around the world [1,2]. Internationally, there have been increasing efforts to utilize high enthalpy geothermal fields associated with volcanic systems, with geothermal power now providing a sizeable share of national electricity generation in Kenya (40\%), Iceland (29\%), El Salvador (25\%) and New Zealand $(18 \%)$ [3]. On a global scale, the total installed capacity from geothermal technologies increased by $3.649 \mathrm{GW}_{\mathrm{e}}$ to nearly $15 \mathrm{GW}_{\mathrm{e}}$ in the period 2015-2020, a $27 \%$ increase. A further increase of 19\% is projected over the period 2020-2025 [4]. In addition, direct uses of geothermal energy, which date back to Paleolithic times when hot springs were first used for 
bathing, are also increasing and include district heating, space heating, industrial and agricultural processes, swimming pools and spas $([5,6]$.

Despite its small population of only around 368,000, Iceland has become one of the leading global players in the geothermal industry, with the nation's expertise being exported around the world $[7,8]$. Geothermal energy sources account for approximately $66 \%$ of all primary energy use [9]. Direct utilization of the resource includes mainly space heating $(43 \%)$ but also includes bathing and recreation, fish farming, greenhouses, industrial processes, and snow melting [10]. Indirect uses of geothermal energy have expanded considerably over the past three decades to meet the growing demands of the industrial sector in Iceland, particularly aluminum smelters [11]. As of March 2021, the total installed capacity of geothermal power in Iceland is 753.3 MW [12].

Given the complex variety of direct and indirect uses of geothermal power in Iceland, considerable effort has gone into mapping stakeholders and establishing collaborative industry-wide networks in the form of an 'energy cluster'. More than 60 stakeholders have been identified in the Icelandic geothermal industry, with the cluster network aiming to formulate new economic avenues and opportunities to export expertise [13]. Initially, the role of geothermal power in driving a sustainability transition was in reducing dependency on fossil fuels - in Iceland, this was largely motivated by a desire to reduce costly imports and increase domestic energy security [14, 15]. Increasingly, the geothermal industry has also had to consider its role in stimulating more sustainable outcomes at a national level, although Iceland's contribution is arguably now more global in scale given its role in the knowledge economy. Nowadays, the geothermal industry plays an important role in the pursuit of the United Nations' Sustainable Development Goals (SDGs). Goals 7 (Affordable and clean energy) and 13 (Climate action), both of which emphasize the importance of decarbonizing energy systems and economies [16, 17]. Pursuit of Goal 7 , when delivered in accordance with the principles of sustainable energy development, is especially important and likely a pre-requisite for the fulfilment of Goals 1-5 focused on human development, Goal 8 on decent work and economic growth, Goal 9 on industry, innovation and infrastructure, and Goal 13 on climate action $[17,18]$.

Despite knowledge concerning stakeholders and the economic advantages of consultation, collaboration and innovation [13], analysis of the sustainability implications of the Icelandic geothermal industry has tended to take a high-level or systemic overview of national performance. This has been exemplified in several recent publications, such as, the role of geothermal resources in sustainable power system planning [14], studies on the sustainability implications of geothermal power [19-21], and the ecosystem service implications of geothermal power [22-24]. Given the variety of direct and indirect uses of geothermal energy resources in Iceland, the contribution of an energy cluster in fostering innovation, and the burgeoning role of the industry in exporting knowledge to other nations, it is surprising that project specific analysis has not yet been conducted into the contribution of the Icelandic geothermal industry to the generation of sustainability cobenefits that materialize at the stakeholder and project-specific level. This paper seeks to begin to fill this gap in the academic and grey literature, investigating the following research question: how do projects in the Icelandic geothermal energy sector create co-benefits with stakeholders which reflect the integration of sustainable development? The focus of its analysis is on identifying who are the stakeholders, what are the co-created sustainability benefits, and when in the project lifecycle do these occur. In so doing, the analysis will be relevant to other nations seeking to increase utilization of geothermal energy resources, especially those reliant on the input of Icelandic expertise.

This paper is structured as follows. Section 2 sets out the theoretical framework that underpins the paper's ensuing analysis, including an outlining of the project management perspective and delineation of two key terms: sustainable development and sustainable energy development, the latter having been recently thematized in Iceland using stakeholder analysis. In addition, theory behind the co-creation of stakeholder benefits in a project management setting is explored. Section 3 describes the materials and methods, the latter involving semi-structured interviews with project managers working in the 
Icelandic geothermal industry, both in direct and indirect utilization of the resource. Section 4 is a discussion, addressing the policy implications of the study's outcomes and their relevance to other contexts, and Section 5 outlines a brief conclusion and suggested avenues for further research.

\section{Theoretical overview}

\subsection{Project management and project lifecycle perspective}

Project management has existed for thousands of years, even if not officially given this name, however, it is only since the 1970s that it emerged as an ideology, focusing on technology and tools for solving tasks [25]. The aim of project management is to fulfil goals based on multiple, pre-defined factors and deliver outcomes with respect to quality, time and cost [26]. Issues of risk management, cost and schedule control, and teamwork, have become central to project management. Since the 1990s, greater emphasis has also been placed on the importance of human resources and leadership. The project management literature is now extensive and covers a wide variety of topics, with considerable focus on strategies for the delivery of successful projects and stakeholder management [25].

Current-day project management increasingly strives to accomplish multiple objectives. Whilst once the focus was mainly maximizing profits, the pursuit of sustainable development now frequently plays an important role in the daily activities of project managers [27]. This has been driven in no small part by the emergence and significance of the Corporate Social Responsibility movement and multi-scale initiatives such as the United Nations' SDGs $[28,29]$. Often most of the benefits of a project materialize at its endpoint. The same is generally true when pursuing sustainable development, however, these benefits may still emerge during the development of a project [26, 27]. Consideration of the project lifecycle constitutes part of the modern-day evolution of project management, one which is now much more considerate of stakeholder needs [30]. This study will utilize the seven-step project lifecycle (Figure 1) to consider the various stages and ways in which project stakeholders in Iceland's geothermal industry source sustainability benefits.

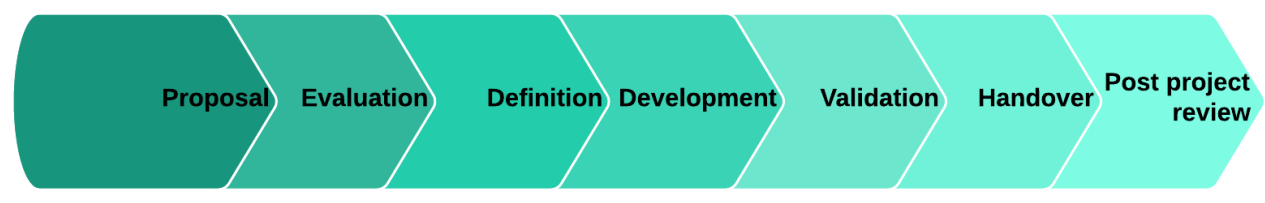

Figure 1. Seven-step project lifecycle. ${ }^{1}$

In this schematic, the first stage, the proposal, defines needs and opportunities, which form the basis of the project. The second step, evaluation, involves assessment of the proposal's merits with respect to scope, time, cost, suitability and alignment with the ambitions of other projects, and policy/regulatory accordance [31, 32]. Thirdly, the project is defined, a process of clarity building that assists in the minimization of risk [31, 32] and pursuit of long-term sustainability goals [33]. At this stage, stakeholders are also identified and analyzed [34]. Development constitutes the fourth step, whereby the project is advanced through design, development, innovation and creativity. Step five, validation, involves the testing and examination of whether the project meets the objectives set out at the start of the design process. During handover, step six, the project is completed and passed on to those will apply it, such as specific departments within the organization,

1 Author's representation adapted from [31, 32] 
individuals, customers and management bodies. Step seven is a post-project review, during which lessons learned are reflected upon and a critical examination of project success is conducted [31, 32].

\subsection{Sustainable development and sustainable energy development}

The literature on the concept of sustainable development is rich and vast. This paper will not seek to discuss its many contested interpretations, but rather to outline some commonly understood and agreed upon principles. In contrast to the widely used term of sustainability, which is a specific state, sustainable development constitutes a process involving transitions and management. It entails ongoing development that stimulates economic and social benefits without undermining the capacities of the natural resource base. The concept thus refers to a reconciliation whereby sufficient capital is left in place, both in terms of quantity and quality, for future generations to be able to obtain the same benefits, the result being that human well-being is maintained or advanced [34-37].

In the context of energy, the more nuanced and subtle term of sustainable energy development is increasingly applied and will be utilized in this study. In contrast with sustainable development, which places considerable emphasis on economic expansion, the term sustainable energy development has become more widely used by policymakers due to acknowledgement of the external costs of expanded energy production and consumption, which has typically been reliant on fossil fuels [14, 38]. Sustainable energy development has been defined as "the provision of adequate energy services at affordable cost in a secure and environmentally friendly manner, in conformity with social and economic development needs" [39, p. 1]. Over the past two decades, sustainable energy development has become a prominent international policy objective reflective of the challenges confronting modern energy systems, including depleted stocks of fossil fuel resources, increasing demands for energy, and the tackling of climate change [14, 38]. The concept is embedded in the SDGs, with SDG7 (Affordable and clean energy) aiming to ensure access to affordable, reliable, sustainable and modern energy for all [40].

Sustainable energy development has been conceptualized as a series of interrelationships between three dimensions: economic, environmental and social [39]. There are driving forces from the economic dimension which impact the environmental and social states, and the three dimensions are influenced by the policies, regulations and decisions of governance institutions [38, 39]. Recent conceptual work has focused on the identification of general themes in sustainable energy development. Sustainable energy development has been thematized as a series of uni- and bi-directional blows between four overarching themes: access to affordable modern energy services; sustainable energy supply; sustainable energy consumption; and energy security [41]. Iceland-specific analysis, based on stakeholder mapping, semi-structured interviews, focus groups and a Delphi survey, has proceeded to reveal six interrelated themes, as follows: nature conservation; social benefits; energy security; economically efficient energy system; sustainable energy production; and sustainable energy consumption [42,43]. The scope and core features of these themes are summarized in Table 1. It is evident that pursuit of these themes entails consequences for a broad array of stakeholders, including individuals, communities, governance bodies, and the public and private sector. 
Table 1. Sustainable energy development themes and scope in Iceland. ${ }^{2}$

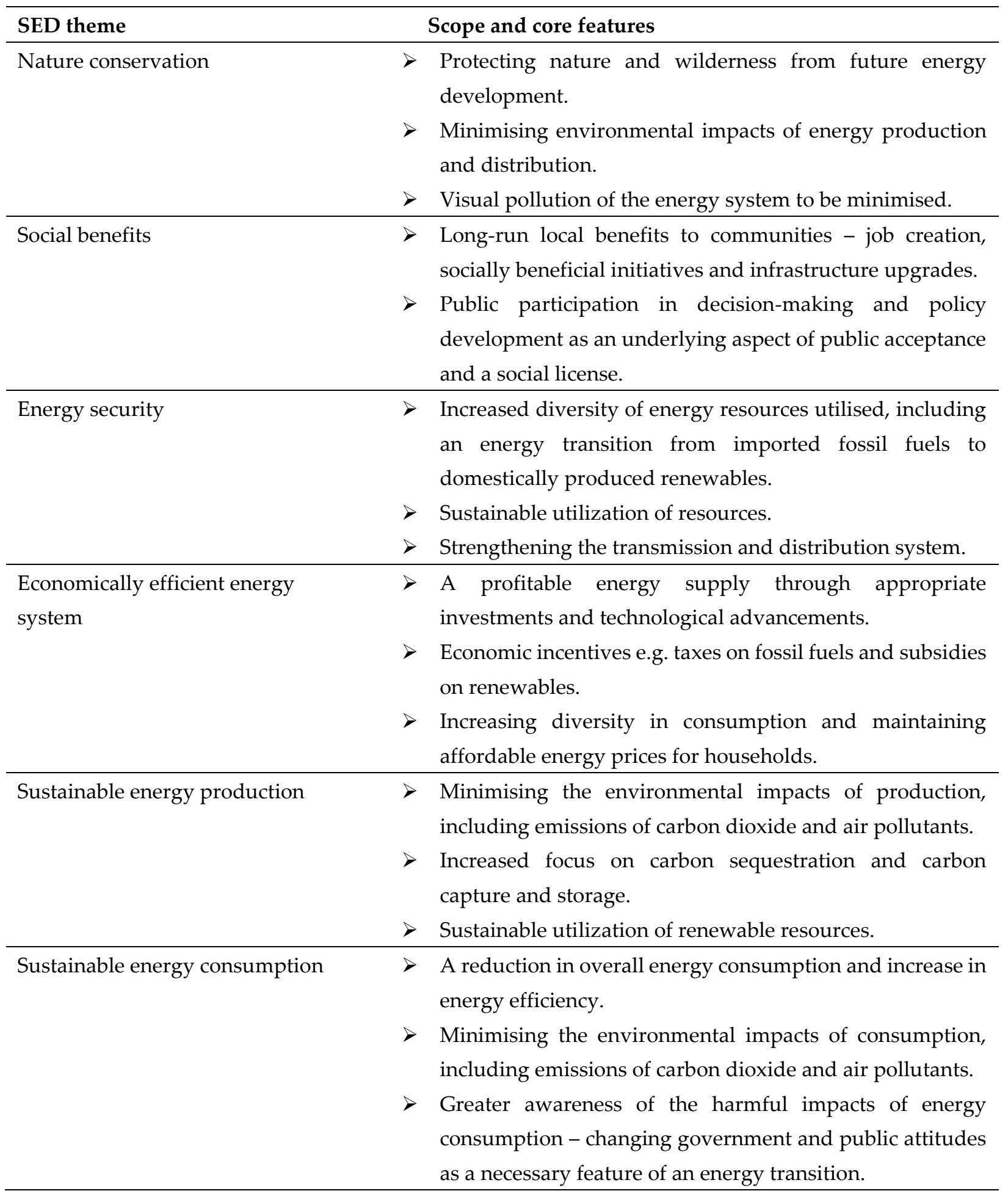

\subsection{Co-created benefits for stakeholders}

The aim of project management, the steps in the project management lifecycle, and thematic representation of sustainable energy development all reinforce the understanding that sustainability benefits permeate via benefits creation (by project managers and stakeholders) and benefits capture (receipt of benefits by stakeholders). Thus, a process of

2 Sourced with permission from [44]. 
co-creation of sustainability benefits is involved [45]. The specific focus of this paper is on sustainability benefits, however, regardless of the type that is co-created, it is evident that these are the source of value creation from projects, and the amount of value depends greatly on the subjective perceptions of the stakeholders [46]. Projects create value through stakeholder collaboration [47, 48], and, by necessity, the fulfilment of sustainable energy development demands integrative thinking on the part of stakeholders across the project lifecycle. Given that the pursuit of sustainable energy development inevitably involves socially constructed, pluralistic and subjective interpretations concerning what represents a benefit and to what degree, it is important that analysis is cognizant of diverse perspectives and different values. A project lifecycle perspective is, therefore, especially useful given its recognition of the phased, evolving and reflective character of projects and project management [45].

This study draws upon the conceptual framework of sustainability benefit co-creation set out in [45] and reproduced in Figure 2.

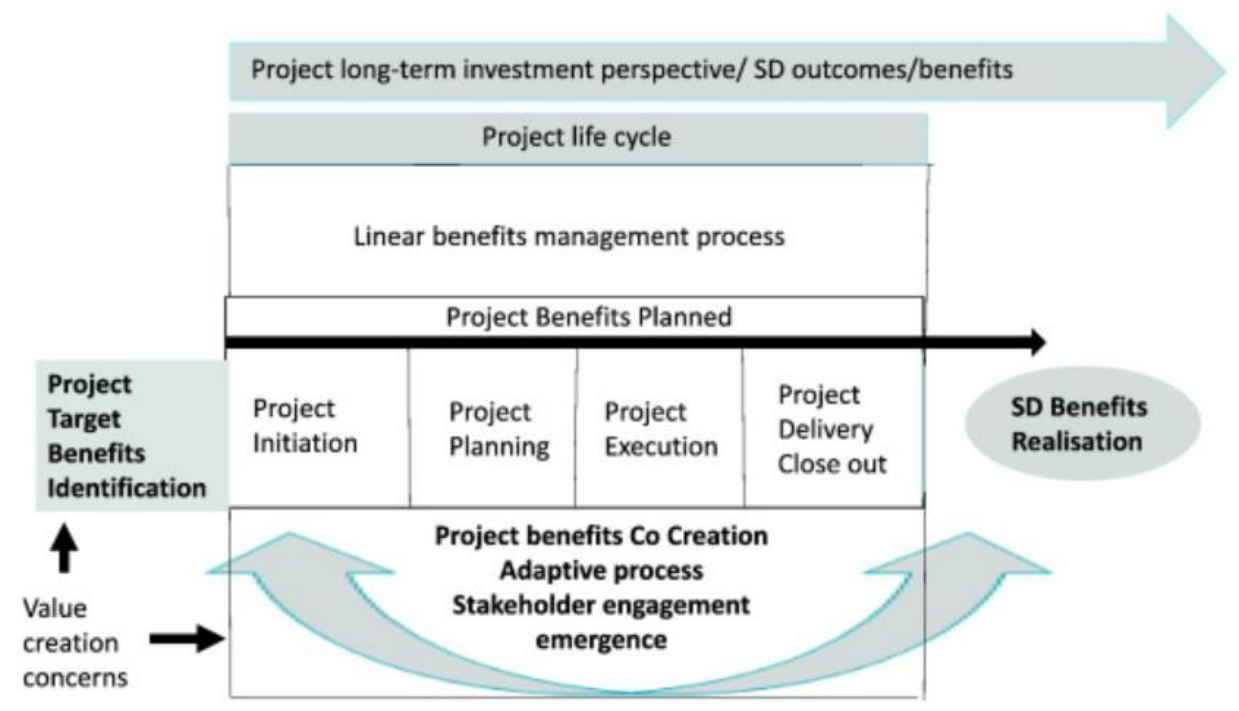

Figure 2. Conceptual framework of co-creation of sustainability benefits in project management. ${ }^{3}$

Figure 2 clearly articulates that the project environment is complex, including multiple stakeholders, dynamism across the project lifecycle, and uncertainty at the outset concerning potential value creation. As [45] contend, it is apparent that a planned, management-dominated approach to the formation of sustainability benefits is insufficient alone, and rather co-creation of benefits is involved, as indicated by Figure 2's recognition that the process of benefit formation incorporates adaptation (by learning), stakeholder engagement, and emergence of value creation over time. It is thus transformative in character.

The process of creating sustainability benefits commences at the outset of the project. This is apparent in steps one and two of the seven-step lifecycle, when investment decisions are determined, and then especially in step three focused on definition. These are the steps of project initiation in Figure 2, and they constitute the linear, management-led part of the process of sustainability benefit creation. Thereafter, co-creation and realization of benefits emerges through stakeholder engagement, adaptivity, and the fluid emergence of benefits and value creation for a diverse array of stakeholders.

\footnotetext{
${ }^{3}$ Sourced with author's permission from [45].
} 


\section{Materials and Methods}

\subsection{Phenomenon of interest and research methods}

Co-creation of stakeholder benefits and sustainable energy development within projects in the geothermal sector in Iceland is the multidisciplinary phenomenon of interest in this research. Qualitative inquiry, which was methodology of this research, aims to make sense of, and interpret, data in terms of meaning, relating it to the context and the situation studied [49]. Qualitative methodology provides several options with regards to specific research methods, of which the interview is the most commonly applied one, providing researchers with an opportunity to collect rich data by asking questions prepared beforehand. Furthermore, in-depth explanations can be acquired, and follow-up questions posed [50].

The language in which interviews are conducted can be a limitation in qualitative research [51], however, this was not the case in this research as the interviews were conducted in Icelandic, which is the mother tongue of all interviewees. Interviews were transcribed and analyzed before the next interview, which enabled development and refinement of the interview frame with additional questions, in line with the emergence of data concept in qualitative research [52]. Notes about immediate impressions/reflections on the interviews were taken, including ideas, further questions and reactions of the interviewee.

Table 2 sets out the participants in the interviews. These were identified using stakeholder mapping - a stakeholder map of the Icelandic geothermal cluster has already been developed [53]. We considered this to constitute a credible sampling strategy given that the stakeholder map constituted a body of recently cultivated knowledge on the diversity and multi-levelness of stakeholders in this sector. Interviewees consisted of 6 men and 5 women, with age diversity ranging from interviewee in their 30 s to 60 s, all of who have experience in geothermal energy development projects in Iceland on managerial level. In Table 2, interviewees and companies are anonymized through lettered and numeric denotations, respectively. Companies were categorized in accordance with the European Union's classification as whether they were micro (0-10 employees), small (less than 50 employees), medium (up to 250 employees) or large (250+ employees) [54].

Table 2. Interview participants.

\begin{tabular}{|c|c|c|c|c|c|c|c|c|}
\hline Interview no. & Interviewee & Gender & Job position & Company no. & Industry & Company size & $\begin{array}{l}\text { Date of inter- } \\
\text { view }\end{array}$ & $\begin{array}{l}\text { Interview } \\
\text { length }\end{array}$ \\
\hline 1 & A & Female & $\begin{array}{l}\text { Environmen- } \\
\text { tal organiza- } \\
\text { tion }\end{array}$ & 1 & Engineering & Medium- & 06/10/2021 & $00: 29: 48$ \\
\hline 2 & B & Female & $\begin{array}{l}\text { Quality and } \\
\text { environmental } \\
\text { manager }\end{array}$ & 2 & $\begin{array}{l}\text { Electricity ser- } \\
\text { vices }\end{array}$ & Medium- & $06 / 10 / 2021$ & $00: 37: 44$ \\
\hline 3 & $\mathrm{C}$ & Male & $\begin{array}{l}\text { Manager of } \\
\text { mechanical di- } \\
\text { vision }\end{array}$ & 3 & Engineering & Medium- & $06 / 10 / 2021$ & $00: 34: 28$ \\
\hline 4 & $\mathrm{D}$ & Female & $\begin{array}{l}\text { Professional } \\
\text { leader in sus- } \\
\text { tainability }\end{array}$ & 4 & $\begin{array}{l}\text { Electricity } \\
\text { generation }\end{array}$ & Large & $18 / 10 / 2021$ & $00: 29: 37$ \\
\hline
\end{tabular}




\begin{tabular}{|c|c|c|c|c|c|c|c|c|}
\hline 5 & $\mathrm{E}$ & Male & $\begin{array}{l}\text { Mechanical } \\
\text { engineer }\end{array}$ & 5 & Engineering & Large & $20 / 10 / 2021$ & 00:40:31 \\
\hline 6 & $\mathrm{~F}$ & Male & $\begin{array}{l}\text { Business man- } \\
\text { ager in sus- } \\
\text { tainable fi- } \\
\text { nancing }\end{array}$ & 6 & Finance & Large & $29 / 10 / 2021$ & $00: 36: 28$ \\
\hline 7 & G & Male & $\begin{array}{l}\text { Division man- } \\
\text { ager }\end{array}$ & 7 & Utilities & Medium & $02 / 11 / 2021$ & $00: 35: 25$ \\
\hline 8 & $\mathrm{H}$ & Male & $\begin{array}{l}\text { Director of ge- } \\
\text { othermal de- } \\
\text { velopment }\end{array}$ & 8 & $\begin{array}{l}\text { Electricity } \\
\text { generation }\end{array}$ & Large & $02 / 11 / 2021$ & $00: 43: 18$ \\
\hline 9 & I & Female & $\begin{array}{l}\text { Director of } \\
\text { district heat- } \\
\text { ing }\end{array}$ & 9 & Utilities & Medium & $12 / 11 / 2021$ & 00:35:37 \\
\hline 10 & $\mathrm{~J}$ & Male & $\begin{array}{l}\text { Managing di- } \\
\text { rector }\end{array}$ & 10 & Energy cluster & Micro & $19 / 11 / 2021$ & 00:53:20 \\
\hline 11 & K & Female & $\begin{array}{l}\text { Innovation } \\
\text { project man- } \\
\text { agement }\end{array}$ & 11 & $\begin{array}{l}\text { Innovative } \\
\text { services }\end{array}$ & Small & $25 / 11 / 2021$ & 00:33:39 \\
\hline
\end{tabular}

\subsection{Interview coding and thematic analysis}

Eleven semi-structured interviews, lasting from 29:37 to 53:20 minutes were conducted with identified stakeholders. Data analyses employed steps provided by [52], which enables establishment of relationships between causal conditions, phenomena, context, intervening conditions, action/interaction strategies and consequences, etc. Corbin and Strauss' (2008) [52] steps of open, axial and selective coding were adopted. These provide many benefits, including emergence of connections, discovering one's own biases, and revisiting data multiple times during the process of analysis.

\subsection{Ethical standpoint / philosophical worldview}

The underlying philosophical beliefs guiding this research are grounded in pragmatism, where no commitment to one reality is made [55]. Instead research is guided by research questions and aims, finding solution to the problems, or intended consequences $[56,57]$. The three core research aims were formulated based on the gap in the existing literature. Answers to these questions provide information for practitioners about the multidisciplinary phenomena of creation of co-benefits with stakeholders in the Icelandic geothermal energy sector through project implementation. Pragmatism enables researchers to use multiple methods, different assumptions, and a variety of approaches to data collection and analysis [50], which was implemented in this research, aiming to provide insights into researched phenomena.

Ethical considerations in this research were made following the recommendations of Bryman and Bell [58]. An invitation to participate contained information about the purpose of the research, researchers and institution that they represent, together with contact 
information should any questions arise. Interviewees were informed that the research results would be presented in a summarized form.

\section{Results}

\subsection{Stakeholders}

Table 3 lists the stakeholders that were cited by interviewees (A-K) as being involved in their projects. In the following section, the most frequently mentioned stakeholders will be examined from the interviewees' perspective - these were employees, customers, municipalities, and national governance and public institutions.

Table 3. Stakeholders mentioned in interviews.

\begin{tabular}{|c|c|c|c|c|c|c|c|c|c|c|c|c|c|}
\hline & $\begin{array}{l}\text { Em- } \\
\text { ployees }\end{array}$ & $\begin{array}{l}\text { Cus- } \\
\text { tomers }\end{array}$ & $\begin{array}{l}\text { Part- } \\
\text { ners } \\
\text { /collab- } \\
\text { orative } \\
\text { groups }\end{array}$ & $\begin{array}{l}\text { Busi- } \\
\text { ness } \\
\text { owners } \\
\text { / em- } \\
\text { ployers }\end{array}$ & $\begin{array}{l}\text { Land- } \\
\text { owners }\end{array}$ & $\begin{array}{l}\text { Munici- } \\
\text { palities }\end{array}$ & $\begin{array}{l}\text { General } \\
\text { public }\end{array}$ & $\begin{array}{l}\text { Na- } \\
\text { tional } \\
\text { govern- } \\
\text { ance } \\
\text { and } \\
\text { public } \\
\text { institu- } \\
\text { tions }\end{array}$ & $\begin{array}{l}\text { Energy } \\
\text { compa- } \\
\text { nies }\end{array}$ & $\begin{array}{l}\text { District } \\
\text { heating } \\
\text { provid- } \\
\text { ers }\end{array}$ & $\begin{array}{l}\text { Electric- } \\
\text { ity sup- } \\
\text { pliers }\end{array}$ & $\begin{array}{l}\text { Engi- } \\
\text { neering } \\
\text { compa- } \\
\text { nies }\end{array}$ & The EU \\
\hline A & & $\checkmark$ & & & $\checkmark$ & $\checkmark$ & & $\checkmark$ & & & & & \\
\hline B & $\checkmark$ & & & & & & & $\checkmark$ & & & & & \\
\hline C & & $\checkmark$ & & & & $\checkmark$ & & & & & & & \\
\hline D & & & & & & $\checkmark$ & & $\checkmark$ & $\checkmark$ & & & & \\
\hline E & & $\checkmark$ & $\checkmark$ & & $\checkmark$ & $\checkmark$ & & & & & & & \\
\hline $\mathbf{F}$ & $\checkmark$ & $\checkmark$ & & & & & & & & & & & \\
\hline G & & & & $\checkmark$ & & $\checkmark$ & $\checkmark$ & $\checkmark$ & $\checkmark$ & & & & \\
\hline $\mathbf{H}$ & $\checkmark$ & & & $\checkmark$ & & $\checkmark$ & & $\checkmark$ & & & & & \\
\hline I & $\checkmark$ & $\checkmark$ & $\checkmark$ & & & & & & & & & & \\
\hline $\mathbf{J}$ & & & & & & & & & $\checkmark$ & $\checkmark$ & $\checkmark$ & $\checkmark$ & \\
\hline K & & & & $\checkmark$ & & $\checkmark$ & $\checkmark$ & $\checkmark$ & & & & & $\checkmark$ \\
\hline
\end{tabular}

\subsubsection{Main stakeholders}

\section{Employees}

Interviewee I stated that Company 9's legacy is long and there is a great deal of inhouse knowledge due to highly experienced employees. Interviewee F voiced that for sustainability projects to be successful, it is important to communicate openly regarding policies and other matters relating to sustainability with customers, employees and other stakeholders. Interviewee $\mathrm{F}$ also mentioned that for sustainability to be implemented into 
the operations of the company, the employees need to ask critical questions that help contribute to encouraging customers to thinking more about sustainability. They talked about how sustainability was ingrained into the DNA of the employees and that his job is to "encourage people to think in terms of the dimensions that are actually formed in this sustainable financial framework."

\section{Customers}

Interviewee $\mathrm{C}$ mentioned that he is in daily communication with his buyers, which can be about anything from smaller service requests to more detailed communication when large projects are progressing. Interviewee E said that when a customer is not technology-oriented, stakeholders are defined at the beginning of the project and then Company 5 takes care of their needs and communication with stakeholders. However, often the clients themselves take care of stakeholder analysis and identifying any conflicts of interest. When Company 5 takes care of the stakeholders in design projects, stakeholders are contacted based on the disputed plan, master plan, and the company submits zoning plans for buildings and receives a construction permit. In contrast, Interviewee I said that Company 9 has a very wide range of customers and most of them want the projects to function on their own and that there is not much direct contact with Company 9.

\section{Municipalities}

Interviewee E said that "municipalities are those who have the organizing power." Interviewees $A$ and $G$ talked about municipalities as being significant stakeholders in new geothermal energy projects, with A commenting that "for you to start construction, you need to get a construction permit from the municipality." The process starts with an Environmental Impact Assessment (EIA) that is reviewed, followed by the national planning agency giving an opinion on the project, then an application for an implementation permit from the municipality, and finally, an operating license is applied for. Interviewee A said that neighboring municipalities are often affected by the power plants in the vicinity, especially regarding noise pollution, and when earthquakes disrupt the activities of power plants that can affect the activities of municipalities. On the same note, Interviewee D articulated that the surrounding communities are most affected by the company's energy production and activities. Regarding communication, she added that it is usually easy to commence a conversation with representatives of municipalities, although the topic of conversation is not always straightforward.

Interviewee $\mathrm{H}$ mentioned that the economic impact of Company 8 operations has spillover benefits for the communities in which their projects are carried out. These include increased employment opportunities in the municipality, generating economic expansion locally and for society.

\section{National governance and public institutions}

According to interviewee A, national public institutions are contacted as a stakeholder at a certain point in the process of a project according to law and regulation, as the company needs to apply for all kinds of permits from public institutions. Interviewee A also said that following a certain process determined by laws and regulations makes it easier for the company to carry out its tasks. Interviewee $C$ said that the environment in which Company 3 operates is competitive, not only in Iceland but also abroad. When looking abroad, the strength of the Icelandic króna is very important and avoidance of double taxation is an important consideration. The government can help reach agreements with the nations that the company considers to be within its market area. Interviewee D said that public authorities, licensors and energy utility companies frame how the activities in Company 4 are carried out, which often overlap with local municipality demands.

Interviewee D added that public bodies, such as the National Energy Authority, set a framework for permits, regulations and laws which in his opinion is "very complex, and very sluggish and it is difficult to make changes that are often needed in geothermal operations as 
it is a rather ever-changing environment." Interviewee G concurred and voiced that public institutions are stakeholders when Company 7 must undertake an EIA on a new geothermal energy venture. Interviewee $G$ said that the legislation governing the geothermal sector in Iceland is necessary, as companies have to comply with laws and regulations which can be a complex process, adding: "but these public utilities usually have a lot of goodwill so this is not often a problem."

\subsubsection{Other stakeholders mentioned}

Interviewee $\mathrm{H}$ said that contractors have a certain power as stakeholders, as Company 8 needs to have access to resources and infrastructure to be able to build efficiently. Interviewee A articulated that it is important that the landowners of projects are satisfied, stating "it may still be rare, but at least it needs to be discussed with them." According to Interviewee $\mathrm{K}$, the European Union is a significant stakeholder since the company operates by virtue of grants that is receives from this institution and must provide satisfactory reports on progress in return. Interviewee $G$ said that the general public is a stakeholder in projects at Company 7 because they are affected when electricity, heat and water are cut off for maintenance, and naturally benefit from multiple energy services when this is not the case. Interview I determined that multiple infrastructure and electricity network support companies were stakeholders - district heating providers, electricity suppliers and engineering companies. Interviewees $\mathrm{E}$ and I stated that business partners were stakeholders and interviewee $\mathrm{C}$ cited business owners.

\subsubsection{Communication with stakeholders}

Except for interviewee J, who declined to do so, all interviewees located their respective stakeholders on the power-influence matrix shown in Figure 3.

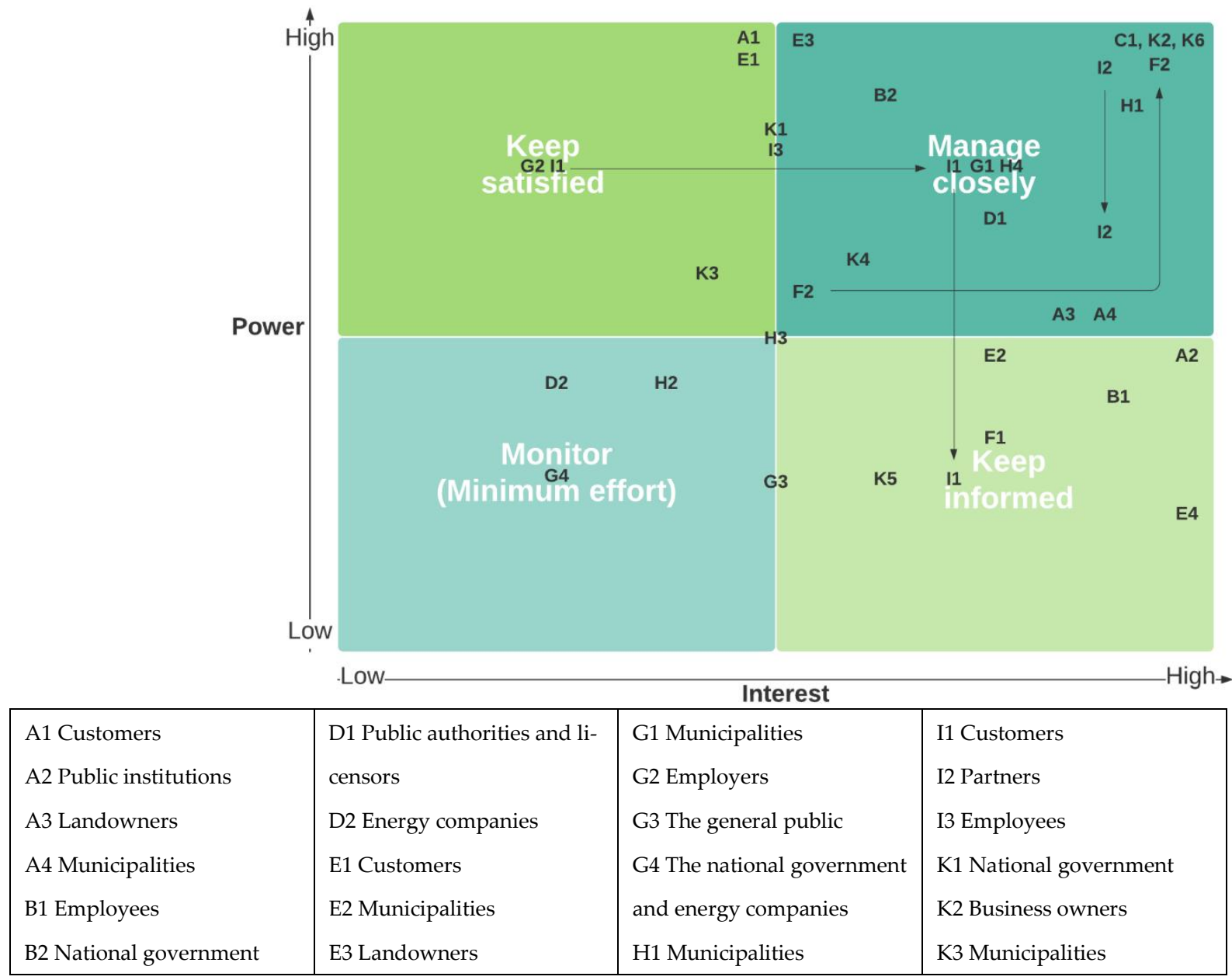




\begin{tabular}{|l|l|l|l|}
\hline C1 Customers & E4 Partners & H2 Contractors & K4 Companies \\
& F1 Departments of the com- & H3 Employment develop- & K5 Residents \\
pany & ment companies & H4 Public institutions & K6 The European Union \\
& F2 Customers & \\
\hline
\end{tabular}

Figure 3. Power-influence stakeholder matrix.

In the case of F2 (Customers) and I1 (Customers), the interviewees mentioned that the level of power-interest depended on the type of customer in question. In the case of I2 (Partners), interviewee I mentioned that the stage in the project lifecycle influenced where the partners are located, and this affected the 'manage closely' aspect.

According to interviewee D, consultations are held with the company's main stakeholders. Regular information meetings on the company's issues facilitated opportunities for discussion to ensure different perspectives were considered. Interviewee D said that it varied as to the stakeholders who sought to take advantage of these opportunities, but that the platform is available.

Interviewee $\mathrm{G}$ said that communication with his five categories of stakeholders is made clear at the beginning of each project and a communication channel established immediately. Interaction with stakeholders is monitored and a vision for what needs to be done in the coming years is created, as well as a Plan B created. Interviewee $\mathrm{H}$ discussed how Company 8 developed a communication plan, also with the aim of guaranteeing regular, open communication with stakeholders anytime during the life of a project. Interviewee $\mathrm{H}$ spoke about an ongoing project, in which a consultation committee of the relevant parties has been established, which usually meets twice a year.

Interviewee I said regarding communication with customers that there is a certain system through which messages are received and that those messages are given priority. However, Interviewee I described how communication with municipalities involves annual meetings with Company 9 to review the future vision and cooperation, summing this up as a debate about "where are you going and where are we going."

\subsection{Sustainability benefits}

Table 4 lists the six SED themes and identifies whether the respective interviewees linked them to the projects of the companies they work for. Examples and excerpts from the interviews are then explored for each theme.

Table 4. Integration of SED themes in projects.

\begin{tabular}{lllll}
\hline Interviewee & $\begin{array}{l}\text { Nature conserva- Social benefits } \\
\text { tion }\end{array}$ & Energy security & $\begin{array}{l}\text { Economically effi- } \begin{array}{l}\text { Sustainable energy } \\
\text { cient energy sys- } \\
\text { tem }\end{array} \\
\text { production } \\
\text { sonsumption }\end{array}$ \\
\hline
\end{tabular}




\begin{tabular}{|c|c|c|c|c|c|c|}
\hline A & $\checkmark$ & $\checkmark$ & $\checkmark$ & & $\checkmark$ & \\
\hline В & $\checkmark$ & $\checkmark$ & $\checkmark$ & $\checkmark$ & $\checkmark$ & \\
\hline C & $\checkmark$ & $\checkmark$ & $\checkmark$ & $\checkmark$ & $\checkmark$ & $\checkmark$ \\
\hline D & $\checkmark$ & $\checkmark$ & $\checkmark$ & $\checkmark$ & $\checkmark$ & \\
\hline E & $\checkmark$ & $\checkmark$ & $\checkmark$ & $\checkmark$ & $\checkmark$ & $\checkmark$ \\
\hline $\mathbf{F}$ & $\checkmark$ & $\checkmark$ & $\checkmark$ & $\checkmark$ & $\checkmark$ & $\checkmark$ \\
\hline G & $\checkmark$ & $\checkmark$ & $\checkmark$ & $\checkmark$ & $\checkmark$ & $\checkmark$ \\
\hline $\mathbf{H}$ & $\checkmark$ & $\checkmark$ & $\checkmark$ & $\checkmark$ & $\checkmark$ & $\checkmark$ \\
\hline I & $\checkmark$ & $\checkmark$ & $\checkmark$ & $\checkmark$ & $\checkmark$ & $\checkmark$ \\
\hline $\mathbf{J}$ & & $\checkmark$ & $\checkmark$ & $\checkmark$ & $\checkmark$ & $\checkmark$ \\
\hline K & $\checkmark$ & $\checkmark$ & $\checkmark$ & $\checkmark$ & $\checkmark$ & \\
\hline
\end{tabular}

\subsubsection{Nature conservation}

Interviewees $\mathrm{C}$ and I opined that construction of geothermal power projects is carried out with a view of having as little impact on the environment as possible, and that the customers of Company 3 are aware that the construction phase is well thought out in this regard. Interviewee D voiced that Company 4 develops work processes and sets requirements for projects so that environmental disruption is kept to a minimum and mitigative measures are applied if an area needs to be disturbed. Interviewee E described how Company 5's environmental policy requires the business to always apply the most environmentally friendly technological solutions and minimize the use of resources. Interviewee $\mathrm{H}$ expressed similar views to interviewees C, D, E and I, outlining that if geothermal ventures enter new and previously undisturbed areas "then it is extremely important that there is in fact a plan for the protection and utilization of land."

\subsubsection{Social benefits}

Interviewee $C$ said that the infrastructure of geothermal activities "has a significant impact on all of the aspects throughout our lives." Interviewee D claimed that activities are always considerate of whether a community's energy needs are fulfilled and thus energy security ensured, and that a project is not undertaken unless the project is promoting benefits for the society. Interviewee D added, "then we also try to see if it is possible to increase the benefits of projects by knowing through innovation and derivative work." Interviewee E mentioned that the social benefit of Company 5's work is that it solves problems and creates more value for society. Interviewee $\mathrm{H}$ asserted that "the company was established in the national interest initially to utilize the country's resources for the benefit of the Icelandic nation", and talked about Company 8 supporting university studies, holding courses, and organizing open events where information about the company's activities is provided. Interviewee I talked about the importance of fairness and intergenerational equity, stating that "our responsibility is to ensure that future generations can access these resources." 


\subsubsection{Energy security}

Interviewee A expressed that planning in geothermal projects addresses the delivery of energy security and claimed that "...these projects usually start because there is a lack of energy." Interviewee $\mathrm{C}$ said that it would be proactive to never rely on one technology alone for energy security, even if it was possible, and explained "we know in history that there can be difficult years for water management in the highlands and then the [geothermal] power plants of course help, to balance it somehow in some way." Interviewee D contended that a long-term vision is the key to energy security, and it is not enough to think about the next 5 years, but to ensure energy security for the next 100 years and easy access to energy. Interviewee $G$ talked about emergency plans that are made with the aim of ensuring safety for the population and that Company 7 ensures that it can maintain its services even if a region will be without electricity. Interviewee $\mathrm{H}$ pointed out that the issue of energy security is not addressed in Icelandic law, so there is perhaps a limited sense of responsibility for ensuring energy security among decision and policymakers.

\subsubsection{Economically efficient energy system}

Interviewee D said that efficiency is one of the key aspects of Company 3's operations and that there is competition in the energy market, which means that efficiency in operations needs to be prioritized. Interviewee $E$ said that Company 5 is involved in the efficient use of resources and that these are utilized as much as possible, declaring "we come up with proposals when we see something that is a waste." Interviewee F mentioned that Company 6 was involved in financing green energy. Interviewee $\mathrm{H}$ reported that the operation of Company 8 is efficient and cost-effective, as well as that capital has been raised in a favorable manner.

\subsubsection{Sustainable energy production}

Interviewee A said that in connection to the extraction of geothermal energy resources, it is being assessed whether too much or too little of the resource is being taken. Interviewee A explained "in the big picture, Iceland has this renewable energy, which is not as common abroad, so we are always comparing ourselves with them, that we are producing renewable energy while it is not done abroad." Interviewee $\mathrm{C}$ mentioned that it is extremely important that energy production is sustainable in the long-run and that the resource is not harnessed in an over-intensive manner, expressing "I think that the development of geothermal power plants in Iceland has now shown that it is successful." Interviewee D voiced that "if energy production is not sustainable, the company will eventually die out." Interviewee H said that there is a strong emphasis on sustainable energy production and that the sustainability standards for hydropower plants are used and that the methodology has been adapted to geothermal energy as well.

\subsubsection{Sustainable energy consumption}

Interviewee $C$ said that the national energy supply needs to be more sustainable for the energy transition to continue to progress, especially so that Iceland's consumption of oil in transportation and shipping can be replaced with more environmentally friendly fuels. Interviewee E mentioned environmentally friendly solutions to reduce waste and make the best use of energy, but this would be best done by increasing the utilization of waste heat from geothermal power production. Interviewee $G$ talked about the fact that in Company 7 operations, methane cars are used in the company's projects for transportation of employees. Interviewee $\mathrm{H}$ said that Company 8 has set goals on how to reduce unsustainable energy consumption, in terms of travel to and from work, flights, vehicles used during working hours and energy consumption in construction projects. They claimed that "in fact, we always do lifecycle analysis for our power plants, which actually maps energy consumption, both during construction and the lifetime, and we try to get as far as we can into the supply chain as well." Interviewee I took a demand-side view, asserting "it is very 
important for us to support households to make the best use of energy because then we need to invest less."

\subsection{Co-benefits of geothermal projects and the project lifecycle}

Interviewee A provided a detailed description of his project from beginning to end within the engineering industry, in particular with respect to the process of conducting an EIA. This is depicted in Table 5's matrix, using Figure 1's seven-step project lifecycle and the six SED themes.

Table 5. Project lifecycle and SED theme assessment by interviewee A.

\begin{tabular}{|c|c|c|c|c|c|c|c|c|}
\hline & & \multicolumn{7}{|c|}{ Project life-cycle phase } \\
\hline & & $\begin{array}{l}\text { Pro- } \\
\text { posal }\end{array}$ & $\begin{array}{l}\text { Evalua- } \\
\text { tion }\end{array}$ & $\begin{array}{l}\text { Defini- } \\
\text { tion }\end{array}$ & $\begin{array}{l}\text { Devel- } \\
\text { opment }\end{array}$ & $\begin{array}{l}\text { Valida- } \\
\text { tion }\end{array}$ & $\begin{array}{l}\text { Hando- } \\
\text { ver }\end{array}$ & $\begin{array}{l}\text { Post } \\
\text { project } \\
\text { review }\end{array}$ \\
\hline \multirow{6}{*}{$\begin{array}{c}\text { SED } \\
\text { Theme }\end{array}$} & Nature conservation & & $\checkmark$ & $\checkmark$ & $\checkmark$ & $\checkmark$ & $\checkmark$ & $\checkmark$ \\
\hline & Social benefits & $\checkmark$ & & & & & & $\checkmark$ \\
\hline & Energy security & & & & & & & $\checkmark$ \\
\hline & Economically efficient energy system & & & & & & & $\checkmark$ \\
\hline & Sustainable energy production & & & & & & & $\checkmark$ \\
\hline & Sustainable energy consumption & & & & & & & $\checkmark$ \\
\hline
\end{tabular}

Interviewee A described the process of establishing and conducting an EIA for a geothermal power project Iceland, with these aspects summarized in accordance with the seven-stage project lifecycle:

1. Proposal: A project is submitted by Company 1 .

2. Evaluation plan: This contains a description of the project and the main impacts of construction.

3. Definition of environmental factors: The possible effects of construction on the environment are scoped out. Interviewee A mentioned birdlife and the sustainability of the geothermal reservoir as examples. Company 1 then proposes how these environmental aspects will be investigated. Once the environmental aspects and the assessment plan have been defined, it is sent to The National Planning Agency. The National Planning Agency evaluates the plan and approves the assessment as a work plan and defines each factor.

4. Development of EIA: Responsibility for conducting the EIA is then handed over to the engineering firm and the next step is a detailed evaluation of the impacts of the planned geothermal project. If necessary, specific experts are called in to study certain aspects of the environment e.g. impacts to flora, fauna and archaeological heritage. This stage should integrate consultation and input from various stakeholders, including the general public. 
5. Validation: The EIA's results are compiled, which provide an assessment concerning whether project has a significant environmental impact and the extent to which these consequences can be mitigated.

6. Handover: Company 1 submits the report to The National Planning Agency, which issues an opinion on whether the planned project will have a large or small impact. The party issuing the exploratory or production license must also demonstrate that the verdict of the National Planning Agency has been taken into account.

7. Post project review: Supervision of project, including adoption of mitigation measures, and reflection on lessons learned.

Interviewee A said that the more stakeholder consultation that occurs, the better, claiming that it helps in the process, "both to open the discussion so that everyone is informed and perhaps to prevent any further conflicts." Thus, ideally there would be a role for stakeholders in stage 1, the proposal, and stage 4, the development of the EIA.

Interviewee D described how there are sometimes trade-offs between pursuit of one SED theme and another, in particular the goal of an economically efficient (i.e. profitable, revenue maximizing, cost efficient) energy system versus nature conservation. They stated that Company 4's modus operandi strives to ensure that natural resources are wellmanaged, but mentioned that some financial incentives and opportunities can encourage over-utilization at times, such as when energy prices are high or new customers come in. Interviewee D explained this dilemma as follows:

"Long-term and short-term perspectives need to be weighed against each other and the company is conscious, but it is, of course, the case that efficiency is often the one [goal] that comes to the fore."

Interviewee D confirmed that capital and income generating possibilities are the factors that weigh very heavily in decision-making. They explained that Iceland is rich in renewable energy resources and these are inexpensive to harness, but said there is room for improvement and explains:

"We have not undertaken such extensive measures as our neighboring countries regarding energy savings and improved energy efficiency, so Icelanders are just very far behind, unfortunately. It's just one of the great opportunities in energy today to think more about improving energy efficiency and stop thinking."

\section{Discussion}

The interviews revealed that project managers in Iceland's geothermal industry believe that a broad variety of stakeholders are relevant and impacted, both positively and negatively, by further power developments. The most frequently mentioned stakeholders were employees, customers, municipalities, and national governance and public institutions. There was widespread consensus across the interviewees that geothermal power projects in Iceland deliver an array of benefits linked to the SED themes, with all claiming the fulfilment of social benefits, energy security and sustainable energy production. It is perhaps more revealing to focus on the few SED themes that were not considered to be satisfied by all participants - nature conservation, an economically efficient energy system, and sustainable energy production.

These findings chime with the results of other studies that have examined the pros and cons of geothermal power projects in Iceland. The pursuit of energy security, decarbonization, reduced environmental impacts and social benefits has been central to the discussion concerning the benefits of Iceland's geothermal energy sector [19, 22, 24].One issue permeates the three themes involving dissatisfaction on the part of the interviews the topic of sustainable utilization of the geothermal energy resource. This has been a hot 
topic in Iceland, not least due to how high-enthalpy fields have been harnessed, and some of the environmental trade-offs pertaining to intensive levels of exploitation for the purposes of supply electricity to heavy industry projects [17]. These include but are not limited to increased greenhouse gas emissions, air and water pollution, noise and visual pollution, and increased incidence of earthquakes [17, 22, 59]. Increased incidence of earthquakes is often associated with unsustainable utilization of geothermal power, which leads for increased need to reinject fluids and drill additional wells in fields to maintain the same power output [60]. In a similar vein to groundwater resources used for drinking water, geothermal energy reserves can take decades or even centuries to replenish without reinjection [60]. Therein, lies the trade-off discussed in the interviews between the pursuit of economic returns in the short-run and what this can lead to in terms of undermining the sustainability of the geothermal resource. This, in turn, has implications for the sustainability of production. In addition, mitigation of some of the environmental consequences of geothermal power production in Iceland, especially carbon dioxide and hydrogen sulfide emissions, entails additional costs of mitigation for resource owners. Innovative projects currently being tested at the Hellisheiði Geothermal Power Plant in Iceland include the reinjection and petrification of effluent carbon dioxide and hydrogen sulfide emissions into basaltic bedrock [61]. In addition, in line with the interviewee discussion concerning minimizing waste and reusing products, effluent carbon dioxide emissions from the Svartsengi Power Plant in Reykjanes are used for the purpose of methanol production, which is a sustainable fuel option for road transportation and shipping [62].

It is evident from the interviews that a relative lack of focus on energy efficiency was one of the drawbacks of not just Iceland's geothermal sector, but the nation's energy system as a whole, which could potentially be addressed via technological innovation. This issue has been recognized in the recent publication (September 2020) of Iceland's energy policy [63], so it is possible that it will be given much greater priority in the coming years. Indeed, there is considerable overlap between the SED themes and the eight strategic objectives of Iceland's energy policy. Directly aligned areas include renewable energy; energy efficiency; smart technology and diversity; benefits to society and consumers; nature conservation and minimized environmental impact; competitiveness and value creation; sound and resilient countrywide infrastructure; a secure energy supply; and energy transition and climate matters. The issue of a need to further decarbonize Iceland's energy system (more sustainable production and consumption) was evident in the interviews, and this will greatly contribute to the fulfilment of Iceland's climate policy goals. These include several objectives for the next three decades, including a 55\% reduction in greenhouse gas emissions by 2030 compared to 1990 levels, carbon neutrality by 2040 and zero fossil fuel consumption by 2050 [64]. Meeting these targets will require Iceland's to generate more renewable energy to facilitate the supportive infrastructure necessary for the electric car market, increased carbon capture from geothermal power plants and heavy industry, and rapid expansion in the production of sustainable fuels for shipping and road transportation, such as 'green hydrogen' $[64,65]$. This implies multiple enhanced SED benefits in the future, provided that the negative externalities of geothermal power can be minimized and/or mitigated. The main benefits include boosted energy security, improved sustainable of energy production, and enhanced sustainability of consumption by reducing the environmental impacts of fossil fuel combustion.

The issue of when SED benefits materialize was also explored in this paper. It is selfevident that the majority of the benefits of geothermal power projects occur after the handover phase in the project lifecycle, when power production commences and multiple energy services - electricity, heating, hot water etc. - are supplied to beneficiaries. However, some projects linked to the geothermal energy sector, including the preparation of an EIA, result in multiple stakeholder benefits across the project lifecycle. The interviews affirmed that from the earliest conception of EIAs, there is a role for national governance agencies, municipalities and the public. Thus, multiple stakeholders provide input, guiding and developing the production of this assessment - with regards to the general public, their input is likely to be greatest during the development phase of an EIA, when stakeholder 
engagement is a legal requirement [66]. This process can help to identify public concerns about the environmental, social and cultural impacts of geothermal energy projects, and help to pinpoint satisfactory mitigative measures.

This paper's findings were based on interview responses by eleven project managers working within Iceland's geothermal energy industry. This approach was useful for gaining industry-specific insights, but potentially entails certain biases concerning the identification of the stakeholders that matter and extent of the sustainability benefits that materialize. In addition, the exact role and scope of the project manager is likely to have considerable influence on their knowledge of the co-benefits of geothermal power - a manager focused on raising finance is likely to be more adroit when it comes to understanding the economically efficient theme of SED, and an environmental manager will have better knowhow on nature conservation. Equally, many project managers do not work across all seven stages of the project lifecycle, meaning that their respective knowledge may be incomplete. Only those interviewees involved in processes from conception through to power production - such as people preparing an EIA - will have awareness of all stages of the project lifecycle and the sustainability co-benefits that may or may not be unfolding.

\section{Conclusions}

This paper sought to fill a gap in the academic literature concerning the project specific sustainability implications of the Icelandic geothermal industry. The focus was on identifying the main stakeholders, recognizing the sustainability co-benefits of projects, and considering when these typically occur in the project lifecycle. Recent theoretical work in Iceland on the six SED themes specific to the nation's energy system were explored with respect to when these manifested in the project lifecycle of geothermal projects. The findings from eleven interviews with project managers in Iceland's geothermal industry affirm that co-benefits accrue to a broad array of stakeholders, including the general public, businesses, municipal government, national government and public institutions, landowners, employees and energy companies involved in supply and distribution. The interviewees were broadly in consensus that the benefits of Iceland's geothermal energy sector permeate all of the SED themes: nature conservation; social benefits; energy security; economically efficient energy system; sustainable energy production; and sustainable energy consumption. However, there was recognition that the issue of energy efficiency had rarely been prioritized in the past, and this had negative consequences for sustainable energy production and consumption. In addition, concerns were voiced about the sustainable utilization of Iceland's geothermal energy resources, particularly resource extraction, and this was mainly due to trade-offs between the pursuit of economic objectives and nature conservation. Efforts were apparent in Iceland to reduce some of the environmental impacts that undermined both sustainable energy production and nature conservation, including the reinjection of effluent carbon dioxide and hydrogen sulfide emissions into basaltic rock. It is evident that Iceland's new energy policy places considerable emphasis on the pursuit of SED, so the findings of this project reinforce the importance of project managers prioritizing its pursuit and seeking to minimize social and environmental externalities across the project lifecycle.

Several future research avenues can be derived from this investigation. These include comparative analysis focused on the opinions of stakeholders in Iceland's geothermal industry, which would facilitate greater understanding of whether the sustainability cobenefits that are perceived by project managers are materializing. In addition, given the ongoing international expansion in the utilization of geothermal energy resources, studies such as this one should be conducted in different cultural contexts. This would be particularly interesting in locations where geothermal power projects have occurred on Indigenous lands, such as in Kenya and New Zealand, where greater social complexities might be inherent than in Iceland. 


\begin{abstract}
Author Contributions: For research articles with several authors, a short paragraph specifying their individual contributions must be provided. The following statements should be used "Conceptualization, DC, IK and IM; DC and IM; software, IK.; validation, DC and IM.; formal analysis, DC and IK; investigation, DC and IK.; resources, IM; data curation, IK; writing - original draft preparation, DC, IK and IM; writing - review and editing, DC, IK and IM; visualization, DC; supervision, DC and IM; project administration, IK; funding acquisition, not applicable. All authors have read and agreed to the published version of the manuscript." Please turn to the CRediT taxonomy for the term explanation. Authorship must be limited to those who have contributed substantially to the work reported.
\end{abstract}

Funding: This research received no external funding.

Conflicts of Interest: The authors declare no conflict of interest.

\title{
References
}

1. Tomasini-Montenegro, C., Santoyo-Castelazo, E., Gujba, H., Romero, R. J., \& Santoyo, E. (2017). Life cycle assessment of geothermal power generation technologies: An updated review. Applied Thermal Engineering, 114, 1119-1136.

2. Stober, I., \& Bucher, K. (2021). Uses of Geothermal Energy. In Geothermal Energy (pp. 43-79). Springer, Cham.

3. BP (2019). BP Statistical Review of World Energy Energy. Retrieved from:

https://www.bp.com/content/dam/bp/business-sites/en/global/corporate/pdfs/energy-economics/statisticalreview/bp-stats-review-2019-full-report.pdf (accessed 14 September 2021).

4. Huttrer, G. W. (2020) Geothermal Power Generation in the World 2015-2020 Update Report. Proceedings World Geothermal Congress 2020 Reykjavik, Iceland. Retrieved from: https:/www.geothermal-energy.org/pdf/IGAstandard/WGC/2020/01017.pdf (accessed 16th September 2021).

5. Cook, D., Davíðsdóttir, B., \& Kristófersson, D. M. (2017). An ecosystem services perspective for classifying and valuing the environmental impacts of geothermal power projects. Energy for Sustainable Development, 40, 126-138.

6. Palomo-Torrejón, E., Colmenar-Santos, A., Rosales-Asensio, E., \& Mur-Pérez, F. (2021). Economic and environmental benefits of geothermal energy in industrial processes. Renewable Energy, 174, 134-146.

7. Zhang, H., Meng, W., \& Zhao, F. (2020, April). Study on the exploitation, utilization and cooperation of geothermal energy between Iceland and China. In IOP Conference Series: Earth and Environmental Science (Vol. 480, No. 1, p. 012010). IOP Publishing.

8. Mikhaylov, A. (2020). Geothermal energy development in Iceland. International Journal of Energy Economics and Policy, 10(4), 31.

9. National Energy Authority. (n.d.). Geothermal. Retrieved from: https://nea.is/geothermal/ (accessed 15 ${ }^{\text {th }}$ September 2021).

10. National Energy Authority. (n.d.). Direct Use of Geothermal Resources. Retrieved from: https://nea.is/geothermal/direct-utilization/ (accessed 15 $5^{\text {th }}$ September 2021).

11. Olafsson, S., Cook, D., Davidsdottir, B., \& Johannsdottir, L. (2014). Measuring countries' environmental sustainability performance-A review and case study of Iceland. Renewable and Sustainable Energy Reviews, 39, 934-948.

12. Iceland Geothermal. (2021). Iceland's Geothermal Power Plants - An Overview as of March 2021. Retrieved from: https://energycluster.is/wp-content/uploads/2021/03/210319_IcelandGeothermal_GeothermalPlants.pdf (accessed 16th September 2021).

13. Gekon. (2011). The Icelandic Geothermal Cluster - Mapping and Mobilization. Retrieved from: http://www.arionbanki.is/lisalib/getfile.aspx?itemid=581adaec-0fb2-419c-9fe9-220f8a503a7f (accessed 16 ${ }^{\text {th }}$ September 2021).

14. Spittler, N., Davidsdottir, B., Shafiei, E., Leaver, J., Asgeirsson, E. I., \& Stefansson, H. (2020). The role of geothermal resources in sustainable power system planning in Iceland. Renewable Energy, 153, 1081-1090.

15. Ioannidis, A., \& Chalvatzis, K. J. (2017). Energy supply sustainability for Island Nations: A study on 8 Global Islands. Energy Procedia, 142, 3028-3034. 
16. Guðlaugsson, B., Fazeli, R., Gunnarsdóttir, I., Davidsdottir, B., \& Stefansson, G. (2020). Classification of stakeholders of sustainable energy development in Iceland: Utilizing a power-interest matrix and fuzzy logic theory. Energy for Sustainable Development, 57, 168-188.

17. Davíðsdóttir, B. (2016). United Nations Sustainable Development Goals and Geothermal Development. Presented at "SDG Short Course I on Sustainability and Environmental Management of Geothermal Resource Utilization and the Role of Geothermal in Combating Climate Change", organized by UNU-GTP and LaGeo, in Santa Tecla, El Salvador, September 4-10, 2016. Retrieved from: https:/orkustofnun.is/gogn/unu-gtp-sc/UNU-GTP-SC-2202.pdf (accessed 16th September 2021).

18. Gunnarsdóttir, I., Davidsdottir, B., Worrell, E., \& Sigurgeirsdóttir, S. (2021). Sustainable energy development: History of the concept and emerging themes. Renewable and Sustainable Energy Reviews, 141, 110770.

19. Shortall, R., Davidsdottir, B., \& Axelsson, G. (2015). A sustainability assessment framework for geothermal energy projects: Development in Iceland, New Zealand and Kenya. Renewable and Sustainable Energy Reviews, 50, $372-407$.

20. Shortall, R., \& Kharrazi, A. (2017). Cultural factors of sustainable energy development: A case study of geothermal energy in Iceland and Japan. Renewable and sustainable energy reviews, 79, 101-109.

21. Shortall, R., \& Davidsdottir, B. (2017). How to measure national energy sustainability performance: An Icelandic case-study. Energy for Sustainable Development, 39, 29-47.

22. Cook, D., Davíðsdóttir, B., \& Kristófersson, D. M. (2017). An ecosystem services perspective for classifying and valuing the environmental impacts of geothermal power projects. Energy for Sustainable Development, 40, 126-138.

23. Cook, D., Davíðsdóttir, B., \& Kristófersson, D. M. (2018). Willingness to pay for the preservation of geothermal areas in Iceland-The contingent valuation studies of Eldvörp and Hverahlíð. Renewable energy, 116, 97-108.

24. Cook, D., Fazeli, R., \& Davíðsdóttir, B. (2019). The need for integrated valuation tools to support decision-makingThe case of cultural ecosystem services sourced from geothermal areas. Ecosystem Services, $37,100923$.

25. Jugdev, K., and Muiller, R. (2005). A retrospective look at our evolving understanding of project success. Project Management Journal, 36 (4), 19-31.

26. Project Management Institute. (2017). The standard for portfolio management (4th ed.). Project Management Institute.

27. Larson, E. W., and Gray, C. F. (2018). Project management: The managerial process. McGraw-Hill Education.

28. Bailey, M., Packer, H., Schiller, L., Tlusty, M., and Swartz, W. (2018). The role of corporate social responsibility in creating a Seussian world of seafood sustainability. Fish and Fisheries, 19(5), 782-790.

29. Camilleri, M. A. (2017). Corporate sustainability and responsibility: creating value for business, society and the environment. Asian Journal of Sustainability and Social Responsibility, 2, 59-74. DOI 10.1186/s41180-017-0016-5

30. Davis, K. (2014). Different stakeholder groups and their perceptions of project success. International Journal of Project Management, 32, 189-201.

31. Buttrick, R. (2003). Robert Buttrick on Project Management. The British Journal of Administrative Management, 34, 2628.

32. Labuschagne, C., and Brent, A. C. (2005). Sustainable Project Life Cycle Management: the need to integrate life cycles in the manufacturing sector. International Journal of Project Management, 23, 159-168.

33. Kuchta, D., and Mrzyglocka-Chojnacka, J. (2020). An Approach to Increase the Sustainability of Projects and their Outcomes in Public Sector through Improving Project Definition. Sustainability, 12, 4804.

34. Blewitt, J. (2014). Understanding Sustainable Development (2nd ed.). Routledge. https://doi.org/10.4324/9781315886459

35. Fernández-Sánches, G., and Rodríguez-López, F. (2010). A methodology to identify sustainability indicators in construct project management - Application to infrastructure projects in Spain. Ecological Indicators, 10, 1193-1201.

36. Costanza, R. (2014). The Role of Natural Capital in Sustainable Development. ecosystem services, 26, $152-158$.

37. Costanza, R., Daly, L., Fioramonti, L., Giovannini, E., Kubiszewski, I., Mortensen, L. F., Pickett, K. E., Ragnarsdottir, K. V, De Vogli, R., and Wilkinson, R. (2016). Modelling and measuring sustainable wellbeing in connection with the UN Sustainable Development Goals. Ecological Economics, 130, 350-355.

38. Gunnarsdóttir, I., Davidsdottir, B., Worrell, E., \& Sigurgeirsdóttir, S. (2020a). Review of indicators for sustainable energy development. Renewable and Sustainable Energy Reviews, 133, 110294.

39. IAEA/IEA. (International Atomic Energy Agency / International Energy Agency) (2001). Indicators for Sustainable Energy Development. Presented at the 9th session of the United Nations Commission on Sustainable Development. Retrieved from: https://www.iaea.org/sites/default/files/indicators.pdf (accessed 16th September 2021). 
40. UN (United Nations). (2015). Transforming Our World: The 2030 Agenda for Sustainable Development. UN Publishing: New York. Retrieved from: https://sustainabledevelopment.un.org/post2015/transformingourworld (accessed 16th September 2021).

41. Gunnarsdóttir, I., Davidsdottir, B., Worrell, E., \& Sigurgeirsdóttir, S. (2021a). Sustainable Energy Development: History of the Concept and Emerging Themes. Renewable and Sustainable Energy Reviews, 141, 110770.

42. Gunnarsdóttir, I., Davidsdottir, B., Worrell, E., \& Sigurgeirsdóttir, S. (2021b). It is best to ask: Designing a staheholder-centric approach to selecting sustainable energy development indicators. Energy Research and Social Science, 74, 101968.

43. Gunnarsdóttir, I., Davidsdottir, B., Worrell, E., \& Sigurgeirsdóttir, S. (2021c). Indicators for sustainable energy development: An Icelandic case study. Energy Policy, (UNDER REVIEW).

44. Cook, D. Davíðsdóttir \& Gunnarsdóttir, I. (2021). A conceptual exploration of how sustainable energy development is implicit in the Genuine Progress Indicator's methodology. Ecological Economics.

45. Keeys, L. A., \& Huemann, M. (2017). Project benefits co-creation: Shaping sustainable development benefits. International Journal of Project Management, 35(6), 1196-1212.

46. Lusch, R. F., Vargo, S. L., \& Wessels, G. (2008). Toward a conceptual foundation for service science: Contributions from service-dominant logic. IBM systems journal, 47(1), 5-14.

47. Matinheikki, J., Artto, K., Peltokorpi, A., \& Rajala, R. (2016). Managing inter-organizational networks for value creation in the front-end of projects. International journal of project management, 34(7), 1226-1241.

48. Artto, K., Ahola, T., \& Vartiainen, V. (2016). From the front end of projects to the back end of operations: Managing projects for value creation throughout the system lifecycle. International Journal of Project Management, 34(2), 258-270.

49. Denzin, N. K., \& Lincoln, Y. S. (Eds.). (2003). Strategies of Qualitative Inquiry (2nd ed.). California: Sage Publications.

50. Creswell, J. W. (2014). Research design. Qualitative, Quantitative, and Mixed Methods Approaches (4th ed.). California: Sage Publications.

51. Goulding, C. (2002). Grounded Theory: A Practical Guide for Management, Business and Market Researchers. Location: Sage Publications.

52. Corbin, J., \& Strauss, A. (2008). Basics of Qualitative Research: Techniques and Procedures for Developing Grounded Theory (3rd ed.). California: Sage Publications.

53. Richter. A. (2016). Mapping the Icelandic Geothermal Energy Sector: A report on the sector and its marketing efforts. Íslandsstofa. Retrieved from: https://smidjan.islandsstofa.is/media/2/mapping-the-icelalandic-geothermal-energy-sector.pdf (accessed 27th September 2021).

54. SME Definition. (2021). European Commission. Retrieved from: https:/ec.europa.eu/growth/smes/sme-definition_en (accessed 29th November 2021).

55. Bacon, M. (2012). Pragmatism: An Introduction (1st ed.). UK: Polity Press.

56. Patton, M. Q. (1990). Qualitative Evaluation and Research Methods (2nd ed.). Newbury Park, CA: Sage Publications.

57. Joas, H., Huebner, D. R., \& Morris, C. W. (Eds.). (2015). Mind, Self, and Society: The Definitive Edition. Chicago: The University of Chicago Press.

58. Bryman. A., \& Bell. E. (2007). Business Research Methods, 2nd edition. Oxford: OUP.

59. Cook, D., Davíðsdóttir, B., \& Malinauskaite, L. (2020). A cascade model and initial exploration of co-production processes underpinning the ecosystem services of geothermal areas. Renewable Energy, 161, 917-927.

60. Cook, D., Davidsdottir, B., \& Petursson, J. G. (2015). Accounting for the utilisation of geothermal energy resources within the genuine progress indicator-A methodological review. Renewable and Sustainable Energy Reviews, 49, 211-220.

61. Karlsdottir, M. R., Heinonen, J., Palsson, H., \& Palsson, O. P. (2020). Life cycle assessment of a geothermal combined heat and power plant based on high temperature utilization. Geothermics, 84, 101727.

62. Helgason, R., Cook, D., \& Davíðsdóttir, B. (2020). An evaluation of the cost-competitiveness of maritime fuels-a comparison of heavy fuel oil and methanol (renewable and natural gas) in Iceland. Sustainable Production and Consumption, 23, 236-248.

63. Government of Iceland. (2020). A sustainable energy future - an energy policy for the year 2050. Retrieved from: https://www.stjornarradid.is/lisalib/getfile.aspx?itemid=e36477fd-3bc1-11eb-8129-005056bc8c60 (accessed 29th November 2021). 
64. European Commission. (2021). The European Union, Iceland and Norway agree to deepen their cooperation on climate change. Retrieved from: https://ec.europa.eu/clima/news-your-voice/news/european-union-iceland-andnorway-agree-deepen-their-cooperation-climate-action-2019-10-25_en (accessed 29th November 2021).

65. Nord News. (2021). A hydrogen plant in the east of Iceland. Retrieved from https://nord.news/2021/10/17/a-hydrogen-plant-in-the-east-of-iceland/ (accessed 29th November 2021).

66. Loomis, J. J., \& Dziedzic, M. (2018). Evaluating EIA systems' effectiveness: a state of the art. Environmental Impact Assessment Review, 68, 29-37. 